\title{
Forest Products Consumption and Trade Deficit in Greece during the Financial Crisis: A Quantitative Statistical Analysis
}

\author{
Panagiotis Koulelis \\ School of Geography and the Environment, Environmental Change Institute, University of Oxford, Oxford, UK \\ Email: panagiotis.koulelis@ouce.ox.ac.uk
}

Received 22 March 2016; accepted 18 April 2016; published 21 April 2016

Copyright (C 2016 by author and Scientific Research Publishing Inc.

This work is licensed under the Creative Commons Attribution International License (CC BY).

http://creativecommons.org/licenses/by/4.0/

(c) (i) Open Access

\begin{abstract}
During the economic crisis in Greece, the national forest sector wounded by a serious decline in demand. The national forest sector faced an important decline in forest products consumption. The paper examines the quantitative changes in the above consumption regarding several wood products categories. The results indicated that a very important decline in consumption per capita took place after 2008. Moreover, an unwanted positive relationship between GDP and the forest products trade deficit is confirmed. During the crisis, the continuant reduction of GDP brings reduction on deficit in trade of forest products while an important increase of exports occurs. However, the results also show that policy makers must act immediately in order to stop the total collapse of the sector.
\end{abstract}

\section{Keywords}

Greek Forest Sector, Consumption, Forest Products, Deficit, Correlation

\section{Introduction}

The geographical and the climate conditions in Greece are not allowing important production of wood and wood products. Most of the forest area is located at high mountains and slopes and the production is limited. Koulelis P. [1] placed Greece among low-productivity EU countries. The forests are characterized by pure management and the domestic demand is mostly covered by imports from commercial firms. Only one productive forest is eco-certified (by the Forest Stewardship Council), and covers about 31,500 ha even that national policy strongly promotes the implementation of a national forest certification system [2]. Arabatzis G. and Klonaris S. [3] showed that the consumption of all wood and wood products in Greece was based greatly on imports, necessi-

How to cite this paper: Koulelis, P. (2016) Forest Products Consumption and Trade Deficit in Greece during the Financial Crisis: A Quantitative Statistical Analysis. Open Journal of Business and Management, 4, 258-265.

http://dx.doi.org/10.4236/ojbm.2016.42027 
tating every year a great proportion of public expenditure.

The global financial crisis, the complete derailment of the 2009 public deficit and the exceedingly high, though until then seemingly manageable, public debt pushed the country into an insolvent financial position [14]. It is reported that an overvalued euro has caused the largest ever drop in Greece's GDP growth since World War II [5]. The decline of GDP/cap is presented in Figure 1. Before the beginning of the financial crisis, the GDP/cap is almost at 32.000 \$ per capita. After that, an important downward trend is observed. In particular in 2014, the levels of GDP were under the 22,000 \$ per capita, following a serious decrease of 32.6\% (Table 1).

The Greek construction industry has been severely struck by the financial crisis of recent years [6]. Greek households cut back on their consumption expenditure by a commensurate percentage of almost 30\% [4].

As an expected result of the above, the demand for wood and wood products collapses. On the other hand, the demand for wood products is one of the main drivers of investment in forest management [7]. During the last decades, the investment in forest production looks really as a side issue and no intention is given by the decision makers. Greece has always had a trade balance deficit problem, but it became unprecedented during the euro years. From an annual average of 25 billion in euro trade deficit in the pre-euro period, it became 33 billion euro in the euro years (2002-2014), reaching annual values of 44 billion euro during the three years before the crisis (2006-2008) [5]. Part of the trade balance deficit also concerns the forest products trade deficit. The above deficit for Greece has continuously increased over the years. Specifically, as Koulelis P. [8] explained, after 2001, when in the rest of the EU the forest products trade deficit was decreasing, in Greece increased rapidly, reaching $\$ 1.2$ billion in 2008 compared to $\$ 293$ million in the 1980s and \$778 million in the 1990s.

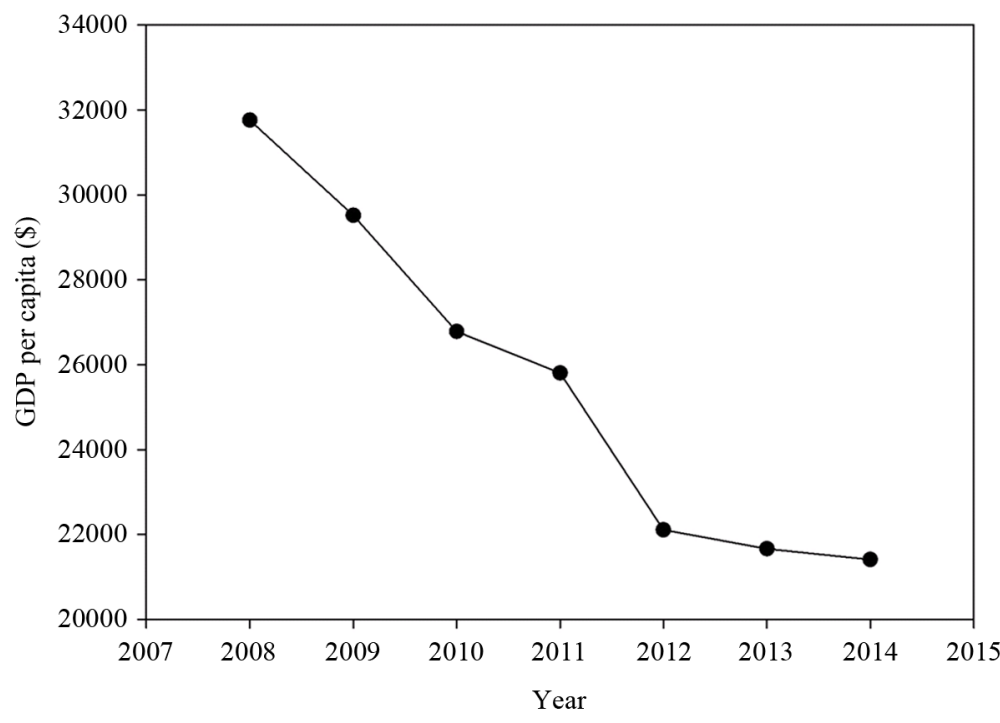

Figure 1. Greek per capita Gross Domestic Product at current prices in US \$. Source: United Nations.

Table 1. Quantitative changes in consumption per capita during the economic crisis.

\begin{tabular}{|c|c|c|c|c|}
\hline & $\begin{array}{c}\text { Estimated sample } \\
\text { period }\end{array}$ & $\begin{array}{c}2008 \\
\text { Value in US\$ }\end{array}$ & $\begin{array}{l}2014 \\
\text { Value in US\$ }\end{array}$ & Total change \\
\hline GDP/cap & 2008-2014 & 31.758 & 21.414 & $-32.6 \%$ \\
\hline $\begin{array}{c}\text { Categories }^{1} \\
\text { (T) }\end{array}$ & $\begin{array}{c}\text { Estimated sample } \\
\text { period }\end{array}$ & $\begin{array}{c}\text { Consumption per cap } \\
2008 / 2009\end{array}$ & $\begin{array}{c}\text { Consumption per cap } \\
2014\end{array}$ & Total change \\
\hline Roundwood & 2008-2014 & 0.20 & 0.15 & $-20.6 \%$ \\
\hline Sawnwood & 2008-2014 & 0.07 & 0.03 & $-50.8 \%$ \\
\hline Wood based panels & 2009-2014 & 0.10 & 0.04 & $-83.6 \%$ \\
\hline Fuel wood & 2009-2013 & 0.09 & 0.11 & $+17.2 \%$ \\
\hline
\end{tabular}

${ }^{1}$ The wood pulp category is missing due to unreadable data in order to calculate the apparent consumption. 
The main scope of this study is to analyze the impact of the financial crisis on the forest products apparent consumption and forest products trade deficit in Greece. Moreover, GDP per capita is taken as an important variable in order to show the relationship between development of GDP and forest products trade deficit (FPTD). The analysis of the deficit's changes over time in terms of providing benefits to the forest sector is presented. Based on the above, main policy actions are proposed.

\section{Material and Methods}

The data for the calculation of the deficit and consumption of forest products [(forest products + (total)] was collected from FAOSTAT [9] and the data about GDP was collected from the United Nations Database [10]. The first part of the quantitative analysis was performed using percentage differences across the examined categories after 2008, when the crisis began. The categories that were examined are Roundwood, Sawnwood (total), Wood-based panels, and Fuelwood. In order to determine that there is a statistically significant relationship and indicate some causality between Gross Domestic Capital per capita (GDP/cap) and forest products trade deficit (FPTD), correlation and linear regression analysis was conducted. The correlation analysis was conducted using the Pearson correlation coefficient. The Pearson correlation coefficient provides an understanding of how strong or weak a correlation is between two (or more) variables. The use of regression analysis provides all of the essential mechanisms for statistical hypothesis testing, estimates and dynamic analyses [11]. The accuracy of the process was tested using the basic statistical tests of correlation and regression, including the Pearson correlation coefficient, the adjusted $\mathrm{R}^{2}$ and the significance $(\mathrm{P}<0.05)$. For more accurate statistical results were delivered data for a long time series (1970-2014). The statistical analysis was performed with SPSS (version 22.0) statistical package [12].

\section{Results and Discussion}

According to Figure 2, roundwood apparent consumption followed an important decline after 2008. The biggest drop began in 2008, with an annual decline of 36.6\%. An important recovery was observed until 2012, followed by a severe decline. The total decrease of this particular consumption-despite the continuous changes-was $20.6 \%$ (Table 1). Over the double decline than roundwood's decline was observed in the consumption of sawnwood. The consumers reduced the demand for sawnwood by 50.8\% during the crisis (Figure 3), (Table 1). Moreover, the consumption of wood-based panels dropped by $83.6 \%$ (Table 1). Based on the above observations, someone could easily characterize the situation as a total collapse of the wood market. It is important to underline here that sawnwood and panels are common for individual use or use by smaller firms or bigger as well and are associated to the building and constructions sector. In Greece, this particular sector has historically played an important developmental role in terms of supporting the economy of small productive or commercial firms, enforcing the domestic timber production of small sawn mills, keeping the levels of unemployment low, and supporting local communities. Simultaneously, is reported that overall, during the three-year period 2008-2011, the Greek industry lost $7.9 \%$ of its value, equivalent to 1.44 bn $€$. In parallel, lost $37 \%$ of the total workforce, equivalent to about 200.000 positions [13]. The timber industry as it was expected, affected negatively by this recession.

By contrast, the consumption per capita of fuelwood seems to have an increased trend during the crisis. Increasing oil prices in combination with the current economic crisis of the Greek economic system is motive enough for many Greek households to satisfy their energy consumption needs by exploiting Renewable Energy Sources (RES) [14]. Specifically, the consumption per capita of fulewood totally increased by 17.2 \% (Figure 4).

It is reported that in 2011, Greece, together with Italy and Hungary, produced more fuelwood than industrial roundwood [15]. This fact might be explained by the increased demand for fire wood due to all the accessional taxes added to the price of petroleum. It is reported by Greek authorities that in 2008, the production of tax free fire wood ${ }^{1}$ was 205,000 $\mathrm{m}^{3}$ and in 2010 was 790,000 $\mathrm{m}^{3}$ following an important increase. This production decreased in 2011 to $344,000 \mathrm{~m}^{3}$ [3]. This issue also created extra problems to the national Forest Service. These problems are related to the controlling and patrolling of illegal logging, especially inside the broadleaves forests where most of the fire wood is collected. The illegal logging incidents were multiplied and the Forest Service encountered and still encounters many problems with them, mainly because of lack of resources and personnel. Moreover, this kind of consumption is related to alternative cheap ways of heating and is connected with the collapse of personal incomes and the weakness of a part of the consumers to choose petroleum and natural gas as methods for heating. This increasing trend seems to return to previous values after 2013. 


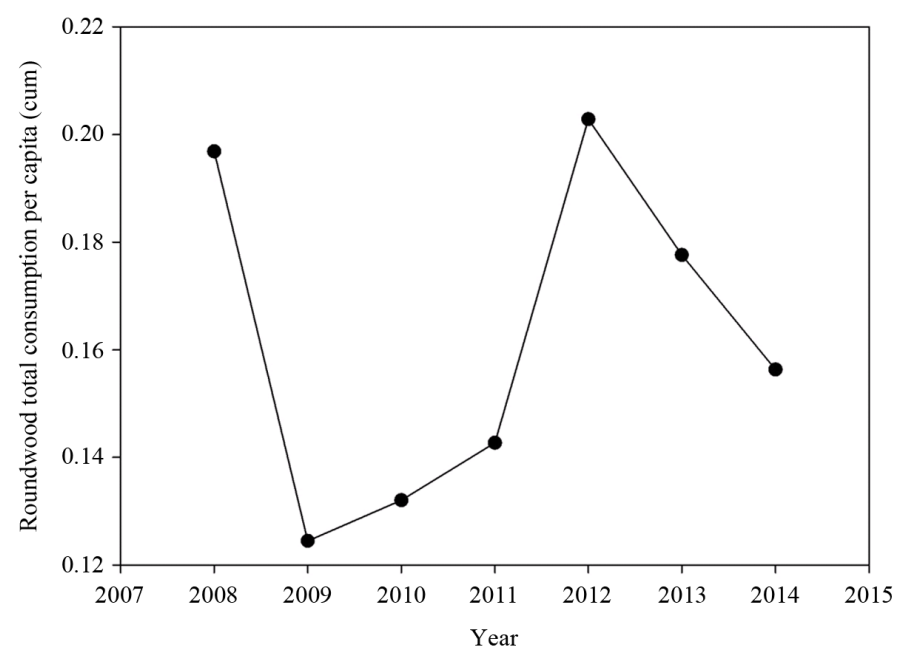

Figure 2. Roundwood per capita consumption during the economic crisis in Greece.

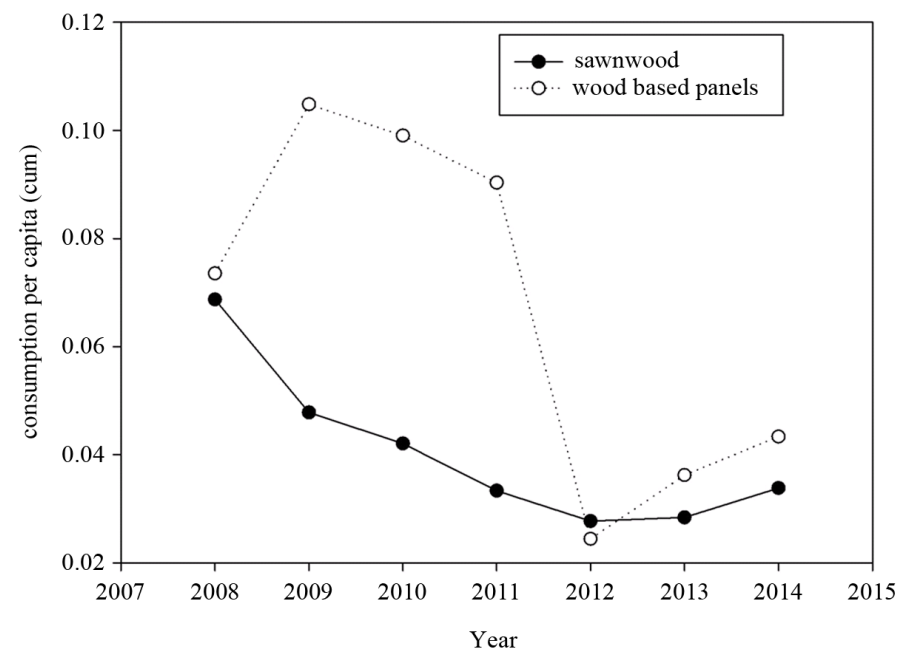

Figure 3. Construction timber per capita consumption during the economic crisis in Greece.

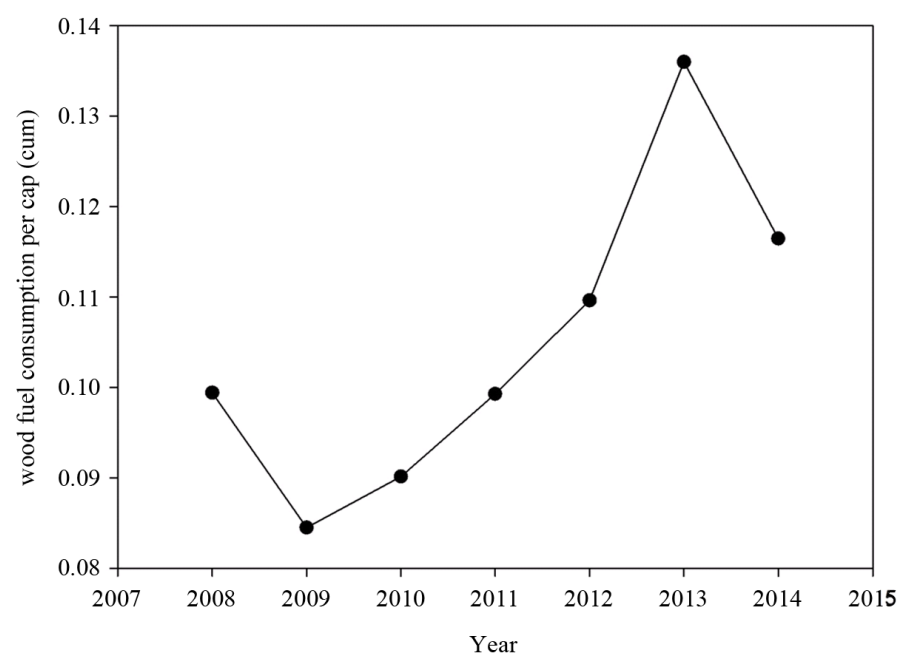

Figure 4. Fuel wood per capita consumption during the economic crisis in Greece. 
The relationship between economic growth and the consumption and trade deficit of a product seems to have two different paths. One path is related to the increase of imports due to increased demand. The other is related to the increase of domestic production in order to satisfy the above demand. Both might be connected to GDP growth. Traditionally in Greece, the GDP/cap seems to have a positive relationship with the forest products trade deficit (FPTD). Both correlation and regression analysis are verifying that fact (Table 2). The result is that the increase of GDP unfortunately promotes increases in deficit over the years (Figure 5). This increase seems to have a connection to the increase of imports. In economic terms, this kind of increase of consumption is due to the increase of per capita income, and is not something that is ideal for the national forest sector. This "bad" growth and the increase of consumption undercut the domestic production and promote the "easy" imports of commodities. It is reported that due to free trade in Europe wood products are imported in Greece in low prices, lower than the domestic average cost of production. For example the price of oak roundwood in the market is almost $40 € /$ cum when the forest service valuate it to $65 € / \mathrm{m}^{3}$ [16]. This situation frustrates the domestic production and boosts the trade deficit.

The increased deficit in forest products over the years means that the country uninterruptedly imported forest products while attaching no relevant significance to domestic exports that might be sourced from the production. The levels of Greek imports in forest products are high, whereas the levels of exports are limited and scarce [8]. Also, the increased demand for forest products due to the increase of leaving standards isn't combined with efforts to be satisfied-at least to a presumable level from national resources.

On the other hand, a decrease in GDP is related to a decrease in forest products trade deficit. The deficit seems to follow the GDP's decline after 2008 (Figure 6). More particularly, the deficit in 2008 was 1,177,564 (1000 \$) and in 2012 it was 685,261 (1000 \$), meaning a total decline of 41.8\%. After that year and the continuant unclear conditions in the Greek economy the deficit followed again an increase until 2014 (total increase by 23\%). That decrease happened mainly due to an increase in exports that have had a positive impact on the deficit. More details about the above increases are presented in Figure 7. The exports in forest products that

Table 2. Linear dependence of GDP/capita on forest products trade deficit for Greece.

\begin{tabular}{cc}
\hline adjusted $\mathbf{R}^{\mathbf{2}}$ & forest products trade deficit \\
\hline GDP/cap & 0.804 \\
Significance level \\
Constant \\
GDP/cap & 0.002 \\
\hline
\end{tabular}

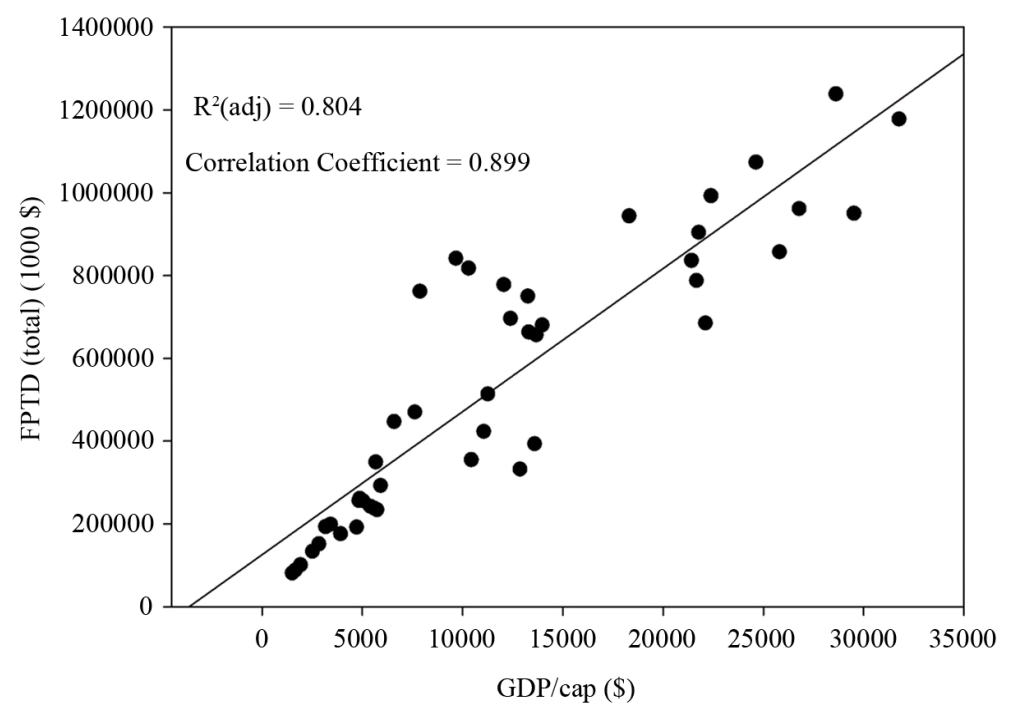

Figure 5. Forest products trade deficit as a function of GDP per capita for Greece. 


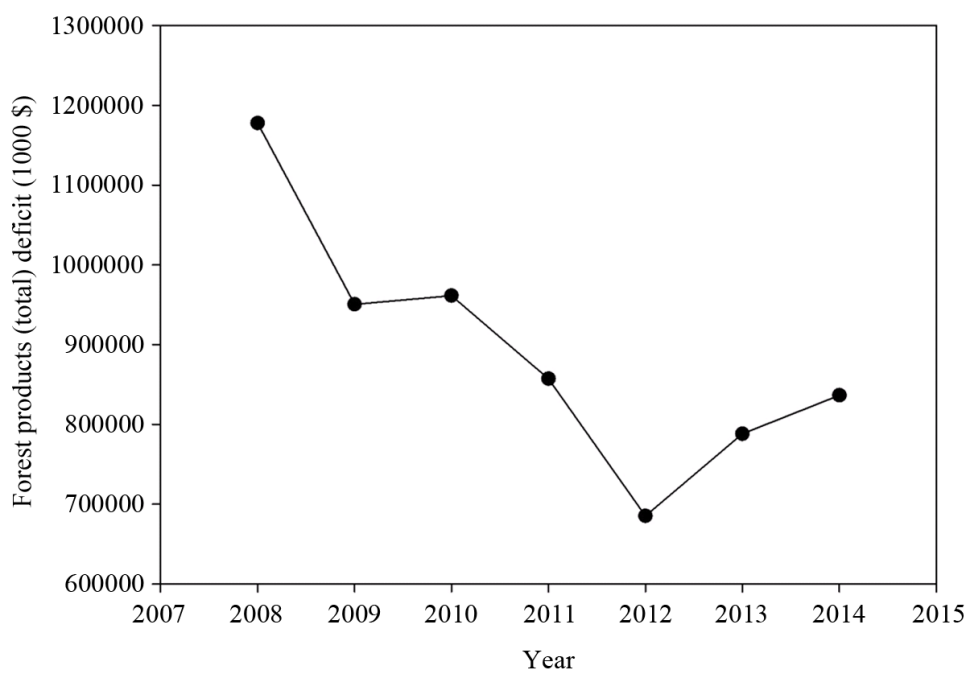

Figure 6. Greek forest products trade deficit during the economic crisis.

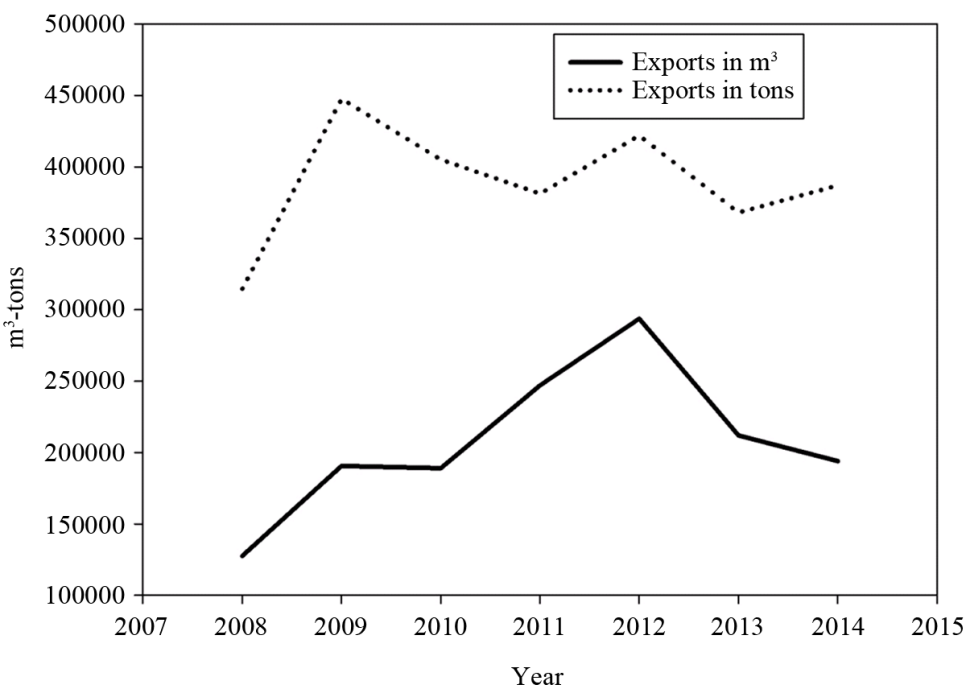

Figure 7. Greek forest product exports during the economic crisis.

measured in $\mathrm{m}^{3(2)}$ after 2008 and until 2014 reached the levels of $194046 \mathrm{~m}^{3}$ from $127590 \mathrm{~m}^{3}$ (total increase 52\%). Simultaneously, in 2008 exported 314,826 T (forest products that measured in tons ${ }^{3}$ ) and on 2014 $387,187 \mathrm{~T}$ (total increase of 23\%). It is important to underline here that the levels of exports could be better in 2014, but a decline was reported in 2012, possibly due to the political situation and the national long-term negotiations regarding the bailout of the country. This rationale is confirmed if someone observes the trend of imports for the same period. According to FAOSTAT the imports of forest products that measured in tons declined by $54 \%\left(2,011,810 \mathrm{~m}^{3}\right.$ on 2008 to $916,246 \mathrm{~m}^{3}$ on 2014) and the imports in tons saw a slight increase by $0.06 \%$ (847,380 $\mathrm{T}$ in 2008 to $897,287 \mathrm{~T}$ in 2014).

\section{Conclusions}

Since 2008, the GDP of Greece has followed a severe decline. The financial crisis drastically injured both the

${ }^{2}$ Includes: Chips and Particles, Hardboard, Ind Rwd Wir (C), Ind Rwd Wir (NC) Other, Ind Rwd Wir (NC) Tropica, Insulating Board, MDF, Particle Board, Plywood, Sawnwood (C), Sawnwood (NC), Veneer Sheets, Wood Fuel Trd, Wood Residues (Source: FAOSTAT).

${ }^{3}$ Includes: Chemical Wood Pulp, Dissolving Wood Pulp Other Paper + Paperboard Newsprint, Other Agglomerates, Other Fibre Pulp, Mechanical Wood Pulp, Printing + Writing Paper, Recovered Paper, Semi-Chemical Wood Pulp, Wood Charcoal and Wood Pellets (source: FAOSTAT). 
market and the demand for forest products, so much so that many firms focused on exports in order to cover their losses.

It is a fact that the levels of consumption per capita of forest products in all of the cases of products that are examined are declined during the economic crisis. In addition, most timber industries or timber traders in the market face huge losses to their income and a huge decline in demand. Many others, mostly small firms with 10 to 15 workers on average are forced to close.

Only the consumption of wood fuels reported an increase, mostly due to the price of petroleum and the taxes related to it. In addition, illegal logging for fire wood increased. The last two years after the intensive patrols and the really huge efforts from the Forest Service the phenomenon was restricted.

A positive relationship between GDP and forest products trade deficit was observed for Greece. This deficit was related to the increasing trend of imports. As it was expected the decline in GDP brought reduction of deficit where a significant and desirable increase of exports occurred.

The economic crisis in Greece in general led to significant losses in the national forest sector. During the economic crisis, the timber industry in Greece was wounded by a decline in demand. Most of the production or commercial firms lost a big part of their customers. The benefits of the decline of imports and the increase of exports of forest products were not as helpful as someone could expect for the viability of the national forest sector.

Greece must re-examine a new policy planning that can possibly straighten the levels of production and exports in forest products and give motivation to the industry (small or bigger). It is well-known that due to geographical and climate reasons, Greece produces fire wood and only small amounts of technical timber. A lot of attention is given to the protection, maintenance, and improvement of national forests. But this is not enough. Only possible new national policies, financial support and investments from the central authorities can enforce sustainable management, and the investigation of all the potentials that are on the market (i.e. plantations are covering only $4 \%$ of the forests) in order to produce certified-qualitative forest products or furniture.

A new national plantation program in poplar (by exploiting the advantage of small rotation) or other kind suitable for construction wood could be an effective solution. In addition, the improvement of the national forests and the certification of the timber should be of high priority. This particular planning under a sustainable frame could reduce unemployment and support economic growth at the local and national level. Currently, every kind of internal support could be really important. Of course the levels of production of wood and products would never be enough to cover the domestic demand or enforce notably the exports. However, a specific plan that includes support of production industries could avoid the large imports from commercial firms as much as possible. The possible participation of Greece in a forest certification organization and the development of a SFM certification system, which will cover all types of forests and forest matters, might increase recognition of the contribution of forestry to the economic development of the country through the broad participation that certification brings [17]. The inversion of the relationship between economic growth and the creation of trade deficit in forest products should be of high priority for policy makers.

\section{References}

[1] Koulelis, P. (2009) Cluster Analysis in Primary Roundwood Production of 25 Countries of European Union. Annals of Forest Research, 52, 163-168.

[2] Hellenic Ministry of the Environment, Physical Planning and Public Works (2008) Country Profile: Greece. National Reporting to the Seventeenth Session of the COMMISSION for Sustainable Development of the UM (UNCSD 17), Athens, December 2008, 13 p.

[3] Arabatzis, G. and Klonaris, S. (2009) An Analysis of Greek Wood and Wood Product Imports: Evidence from the Linear Quadratic Aids. Forest Policy and Economics, 11, 266-270. http://dx.doi.org/10.1016/j.forpol.2009.04.002

[4] Kaplanoglou, G. and Rapanos, V.T. (2015) Evolutions in Consumption Inequality and Poverty in Greece: The Impact of the Crisis and Austerity Policies. Economics Discussion Reports No 2015/9 Economics Department, University of Athens.

[5] Papanikos, G. (2015) The Real Exchange Rate of Euro and Greek Economic Growth. The Journal of Economic Asymmetries, 12, 100-109.

[6] Sfakianaki, E., Iliadis, T. and Zafeiris, E. (2015) Crisis Management under an Economic Recession in Construction: The Greek Case. International Journal of Management and Decision Making, 14, 373.

http://dx.doi.org/10.1504/ijmdm.2015.074015 
[7] FAO (2009) State of the World's Forests 2009. http://www.fao.org/docrep/011/i0350e/i0350e00.HTM

[8] Koulelis, P. (2012) A Study of the Greek Trade Deficit in Forest Products. Current Conditions and Prospects. Forest Systems, 21, 549. http://dx.doi.org/10.5424/fs/2012213-02776

[9] FAOSTAT (2016) http://faostat3.fao.org/home/E

[10] UNSTATS (2016) United Nations Statistics Division-National Accounts. http://unstats.un.org/unsd/snaama/dnllist.asp

[11] Cohen, J. and Cohen, P. (1983) Applied Multiple Regression/Correlation. Analysis for the Behavioral Sciences. 2nd Edition, Lawrence Erlbaum Associates, Inc., New Jersey.

[12] Norusis, M.J. (1997) SPSS Professional Statistics. SPSS Inc., Chicago, 376 p.

[13] ELSTAT (2016) Main Page. Statistics.gr. http://www.statistics.gr/en/home/

[14] Chalikias, M.S., Kyriakopoulos, G.L., Goulionis, J.E. and Apostolidis, G.K. (2012) Investigation of the Parameters Affecting Fuelwoods' Consumption in the Southern Greece Region. Journal of Food, Agriculture \& Environment, 10, 885.

[15] EUROSTAT (2012) Production and Consumption of Wood in the EU27. News Release.

[16] Kakaras, I. (2011) The Production of Wood in Greece and the Applied Forest Policy. Forest Research Institute and WWF Meeting. Greek Forestry: An Asset for the Greek Economy, Athens, 16 May 2011, 4 p.

[17] Georgiadis, N. and Cooper, R. (2007) Development of a Forest Certification Standard Compatible with PEFC and FSC’s Management Requirements. A Case Study from Greece. Forestry, 80, 113-135. http://dx.doi.org/10.1093/forestry/cpm004 